\title{
Association of epididymal secretory proteins showing $\alpha$-lactalbumin-like activity with the plasma membrane of rat spermatozoa
}

\author{
Roy JONES and Colin R. BROWN \\ A.R.C. Intitute of Animal Physiology, Animal Research Station, 307 Huntingdon Road, Cambridge CB3 0JQ, \\ U.K.
}

(Received 12 March 1982/Accepted 27 April 1981)

\begin{abstract}
Three hormonally regulated proteins with mol.wts. of 18500,19000 and 23000 have been shown to associate with the plasma membrane of spermatozoa during maturation in the epididymis. All three proteins showed some $\alpha$-lactalbumin-like activity, suggesting that they may act in concert with epididymal glycosidases and glycosyltransferases to regulate the modification of sugars on membrane-bound glycoproteins.
\end{abstract}

Evidence from a number of laboratories suggests that membrane antigens on spermatozoa change during maturation in the epididymis and that this somehow contributes to the acquisition of motility and fertilizing capacity (Bedford, 1975). In some instances the 'maturation antigens' are homologous with proteins in the epididymal luminal plasma (Jones et al., 1981b; Moore, 1981), suggesting a direct association of the latter with the sperm membrane. However, it has been demonstrated in only a few cases that the proteins which interact with the plasma membrane are actually synthesized in the epididymis. In the rat it has been shown that three proteins with mol.wts. 18500,19000 and 23000 are synthesized and secreted in the caput epididymidis under hormonal control (D'Agostino et al., 1980; Jones et al., 1980). However, it is not known if these proteins have a functional role in sperm maturation. In the present study we have investigated the association of these hormonally regulated proteins with the plasma membrane of spermatozoa during maturation in the epididymis, and examined a recent suggestion that they show $\alpha$-lactalbumin-like activity in the lactose synthetase system (Hamilton, 1981).

\section{Materials and methods}

\section{Materials}

All chemicals were of the highest purity available commercially and were purchased from sources described previously (Jones et al., 1980). Peroxidase-conjugated and fluorescein isothiocyanateconjugated goat anti-(rabbit immunoglobulin G)

Abbreviations used: SDS, sodium dodecyl sulphate; Hepes, 4-(2-hydroxyethyl)-1-piperazine-ethanesulphonic acid. were obtained from Uniscience Ltd. (Jesus Lane, Cambridge, U.K.). Nitrocellulose paper was supplied by Whatman (Maidstone, Kent, U.K.), Dowex-2-Cl (200-400 mesh) ion-exchange resin by Sigma (London) Chemical Co. and UDP-[U- $\left.{ }^{14} \mathrm{C}\right]$ galactose by Amersham International Ltd., Bucks., U.K.

Collection of spermatozoa, rete-testis fluid, epididymal secretions and preparation of detergent extracts

Spermatozoa, rete-testis fluid and cauda-epididymidal plasma were collected from anaesthetized Wistar rats as described previously (Jones et al., $1981 b$ ). Washed spermatozoa were resuspended in $0.264 \mathrm{M}$-sucrose $/ 10 \mathrm{~mm}$-Tris $/ \mathrm{HCl}$, pH 8.0, containing $0.2 \%(\mathrm{w} / \mathrm{v})$ sodium deoxycholate and $0.5 \mathrm{~mm}$ phenylmethanesulphonyl fluoride. The suspensions were incubated at $4^{\circ} \mathrm{C}$ for $45 \mathrm{~min}$, centrifuged at $10000 \mathrm{~g}$ for $10 \mathrm{~min}$, and the supernatants stored at $-20^{\circ} \mathrm{C}$. Preliminary experiments showed that the rate of solubilization of protein by the detergent reached a plateau after $45 \mathrm{~min}$ incubation.

\section{Purification of hormonally regulated proteins}

Three proteins of mol.wts. 18500, 19000 and 23000 were purified from cauda-epididymidal plasma as described previously (Jones et al., 1980). Each protein was more-than- $90 \%$ homogenous on SDS/polyacrylamide gels.

\section{Production of antisera}

Antisera against the purified proteins were raised in rabbits by using a protocol described by D'Agostino et al. (1980). Their specificity was tested on Ouchterlony double-diffusion agar gels against cytosols from brain, liver, kidney, ventral prostate and seminal vesicles, and by immunoelectrophoresis against proteins in blood, cauda-epididymidal 
plasma and rete-testis fluid (D'Agostino et al., 1980).

\section{Assay of $\alpha$-lactalbumin activity}

Proteins were tested for $\alpha$-lactalbumin activity as described by Fitzgerald et al. (1970) with the following exceptions: $(a)$ rete-testis fluid was used as a source of galactosyltransferase (Hamilton, 1981); (b) the reaction mixture was terminated after $60 \mathrm{~min}$ by the addition of $30 \mu \mathrm{l}$ of $0.2 \mathrm{M}$-EDTA.

\section{Electrophoresis}

Proteins were concentrated by precipitation with $9 \mathrm{vol}$. of ethanol, dissolved by boiling for $3 \mathrm{~min}$ in $62.5 \mathrm{~mm}-\mathrm{Tris} / \mathrm{HCl}$, pH 7.4, containing $1 \%(\mathrm{w} / \mathrm{v})$ SDS and $1 \%(\mathrm{v} / \mathrm{v}) \beta$-mercaptoethanol, and analysed on $15 \%(\mathrm{w} / \mathrm{v})$ denaturing polyacrylamide slab gels (Jones et al., 1980). After electrophoresis, proteins were either stained with $0.5 \% \quad(w / v)$ Coomassie Brilliant Blue in an aqueous solution of $40 \%(\mathrm{v} / \mathrm{v})$ methanol/7\% (v/v) acetic acid or transferred to nitrocellulose paper as described below. Relative amounts of proteins on gels were quantified by densitometry with an integrating densitometer (Helena Laboratories).

\section{'Western blotting'}

Proteins separated on SDS/polyacrylamide gels were 'blotted' by electrophoresis on to nitrocellulose paper, and the presence of the 18500- and 19000mol.wt. proteins detected by an immunoperoxidase reaction (Towbin et al., 1979).

\section{Localization of epididymal secretory proteins on spermatozoa}

The distribution of the 18500 - and 19000-mol.wt. proteins on cauda epididymidal spermatozoa was investigated by immunofluorescence using standard techniques (Johnson et al., 1978). All sera were absorbed four times with an equal volume of a mixture of brain, kidney and spleen cells before use.

The 23000-mol.wt. proteins were detected on spermatozoa by using the whole-cell immunoperoxidase technique outlined by Lopo \& Vacquier (1980).

\section{Other procedures}

Total protein was assayed with the Bio-Rad dye-binding kit (Bio-Rad Laboratories, St. Albans, Herts., U.K.), with bovine serum albumin as standard. Radioactivity was measured in $10 \mathrm{ml}$ of Packard scintillation cocktail 299 with a Nuclear Chicago scintillation counter. Efficiency for ${ }^{14} \mathrm{C}$ was approx. $90 \%$.

\section{Results}

The two androgen-dependent proteins with mol.wts. of 18500 and 19000 comprise between 15 and $20 \%$ of the total secreted protein in the caudaepididymidal plasma (Fig. 1a). They are not present in rete-testis fluid and only a trace of protein (approx. 1.3\% of the total) was detected in this region of the gel when sodium deoxycholateextracted proteins from testicular spermatozoa were analysed on SDS/polyacrylamide gels (Fig. 1a). However, sodium deoxycholate extracts from caudaepididymidal spermatozoa showed a 3-fold increase in staining intensity of polypeptides with mol.wts. of 18500 and 19000 (approx. 3.7\% of total protein) relative to testicular spermatozoa. This result was reproducible irrespective of the method employed for washing the spermatozoa.

Antisera raised against the purified 18500 - and 19000 -mol.wt. proteins were found to be specific for these proteins, although they cross-reacted (D'Agostino et al., 1980). When proteins in retetestis fluid, cauda-epididymidal plasma and sodium deoxycholate extracts of spermatozoa were separated on SDS/polyacrylamide gels and transferred to nitocellulose paper, a strong reaction was obtained with the immunoperoxidase technique against cauda-epididymidal plasma, but not against rete-testis fluid (Fig. 1b). A positive reaction was also obtained against sodium deoxycholate extracts of cauda-epididymidal, but not testicular, spermatozoa, indicating that the spermatozoa-associated $18500+19000$-mol.wt. proteins are homologous with those in the cauda-epididymidal plasma. Immunofluorescence microscopy revealed that they were restricted to the head and midpiece region of mature spermatozoa (Fig. 1c).

Recently, Hamilton (1980, 1981) has demonstrated galactosyltransferase and $\alpha$-lactalbumin-like activity in rat rete-testis fluid and cauda-epididymidal plasma. A fraction, designated 'FIII', was prepared from cauda-epididymidal plasma and found to contain the $\alpha$-lactalbumin-like activity (Hamilton, 1981). However, FIII was very impure when analysed on SDS/polyacrylamide gels. The major proteins in it had mol.wts. of approx. $18000-24000$, leading to the suggestion that they were responsible for the activity. Since we have previously characterized androgen-dependent proteins with similar molecular weights from caudaepididymidal plasma (Jones et al., 1980), we were able to test them individually for activity in the lactose synthetase system. Both the 18500 - and 19000-mol.wt. proteins showed some activity (Fig. 2), but this was approx. 100 times less than purified bovine mammary-gland $\alpha$-lactalbumin (control proteins such as a lysozyme, ovalbumin and bovine serum albumin showed no activity). The 32000mol.wt. proteins in rat cauda-epididymidal plasma (Jones et al., 1980) and 20000-mol.wt. proteins in rabbit cauda-epididymidal plasma (Jones et al., 


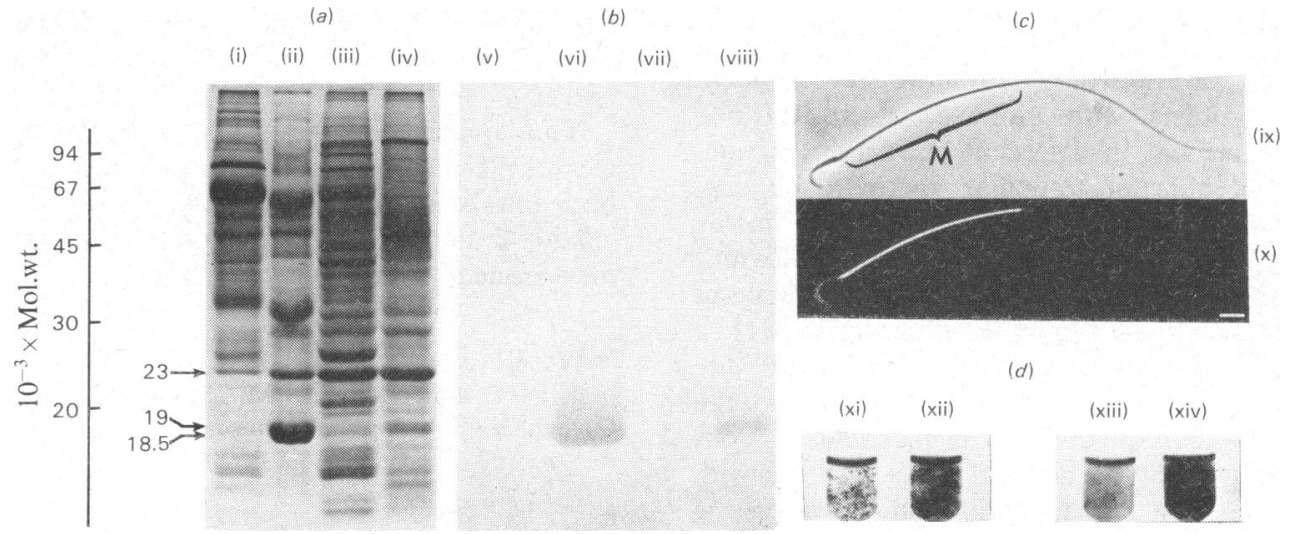

Fig. 1. Detection of epididymal secretory proteins on spermatozoa

(a) SDS/polyacrylamide-gel electrophoresis of proteins in rete-testis fluid (i), cauda-epididymidal plasma (ii), and sodium deoxycholate extracts of testicular (iii), and cauda-epididymidal spermatozoa (iv) stained with Coomassie Blue. Each track received approx. $150 \mu \mathrm{g}$ of protein. (b) Immunoperoxidase reaction using antiserum against the 18500 - and 19000-mol.wt. proteins after transfer of proteins shown in (a) to nitrocellulose paper by 'Western blotting'. (v) Rete-testis fluid; (vi) cauda-epididymidal plasma; (vii) testicular spermatozoa; (viii) cauda-epididymidal spermatozoa. (c) Distribution of $18500+19000$ mol.wt. proteins on cauda-epididymidal spermatozoa. (ix) Phase-contrast. (x) u.v. illumination. Abbreviation used; M, midpiece. The bar represents $5 \mu \mathrm{m}$. $(d)$, Whole-cell immunoperoxidase detection of 23000-mol.wt. protein on testicular (xi and xii) and cauda-epididymidal (xiii and xiv) spermatozoa. Tubes xi and xiii, pre-immune serum; tubes xii and xiv, immune serum.

[18 500- and 19000-mol.wt. proteins] $\left(10^{-5} \mathrm{M}\right)$

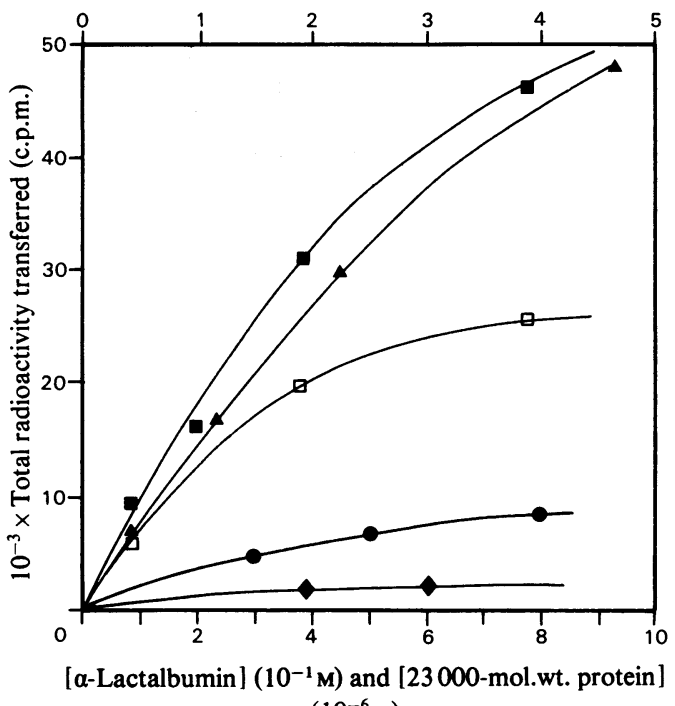

$\left(10^{-6} \mathrm{M}\right)$

Fig. 2. a-Lactalbumin-like activity of purified epididymal secretory proteins

Purified epididymal proteins with mol.wts. of 18500 $(\bigcirc), 19000(\diamond)$, and $23000(\square)$ were tested for $\alpha$-lactalbumin-like activity with glucose as acceptor (see the Materials and methods section): $\Delta$, purified bovine mammary-gland $\alpha$-lactalbumin; $\square$, purified 23000 -mol.wt. protein, with inositol as acceptor. 1981a) also showed no activity. Instead, we found that another hormonally regulated protein with a mol.wt. of 23000 (Jones et al., 1980), which was included in FIII, showed greater activity than either the 18500 - or 19000 -mol.wt. proteins. However, it was still eight times less active than mammary-gland $\alpha$-lactalbumin.

The 23000-mol.wt. protein has some unusual properties. In agreement with Hamilton (1981) we have found that it is equally efficient in catalysing the transfer of UDP- $\left[{ }^{14} \mathrm{C}\right]$ galactose to inositol as to glucose (Fig. 2), whereas only glucose can act as an acceptor with mammary-gland $\alpha$-lactalbumin. Inositol was investigated because it is the major sugar in cauda-epididymidal plasma; glucose has not been detected in cauda-epididymidal plasma from normal animals (Jones, 1979; Hamilton, 1981). The 23000mol.wt. protein is present in rete-testis fluid as well as cauda-epididymidal plasma (Fig. 1a), indicating that it is synthesized in the testis as well as in the caput epididymidis (Jones et al., 1980). It is the major membrane-bound protein in sodium deoxycholate extracts of testicular and cauda-epididymidal spermatozoa (Fig. 1a). An antiserum raised against the secreted 23000 -mol.wt. protein gave a positive reaction against both testicular and cauda-epididymidal spermatozoa in the whole-cell immunoperoxidase procedure of Lopo \& Vacquier (1980), suggesting that the secreted and membrane-bound proteins are homologous (Fig. 1d). 


\section{Discussion}

The demonstration that two androgen-dependent secretory proteins with mol.wts. of 18500 and 19000 are present in detergent extracts of caudaepididymidal but not testicular spermatozoa suggests that they become associated with the plasma membrane during maturation in the epididymis. Other workers have also reported changes in sperm surface antigens during epididymal maturation (Lea et al., 1978; Moore, 1981; Gaunt, 1982), but were not able to ascribe any enzymic activity to the particular proteins involved. The mechanisms controlling the association of epididymal proteins with the sperm surface and their disposition within the membrane are not known. By analogy to the fixation of complement (Lachmann \& Hobart, 1978), a conformational change in the structure of secreted proteins could expose internal hydrophobic domains which could then interact directly with membrane lipids. This possibility is supported by preliminary experiments with a lipophilic photo-activatable nitrene reagent described by Owen et al. (1980), which labels two polypeptides on cauda-epididymidal spermatozoa with mol.wts. of 18500 and 19000 , suggesting that they are in contact with the lipid bilayer (R. Jones \& C. R. Brown, unpublished work). Alternatively, they may bind to specific receptors on the plasma membrane. If the receptors were sequestered into different areas of the membrane during spermiogenesis, then it would help explain the restricted distribution of sperm surface antigens which arise during epididymal maturation.

The association of proteins showing $\alpha$-lactalbumin-like activity with the plasma membrane of spermatozoa suggests they may function in concert with epididymal glycosidases and glycosyltransferases (Jones, 1979; Hamilton, 1981) to regulate the sequential removal and addition of sugar residues on membrane-bound glycoproteins, in a manner analogous to differentiation antigens (Feizi, 1981). In the absence of glucose, inositol would function as the carbohydrate acceptor. This hypothesis is supported by the observations of Fox et al. (1982), who have found that a monoclonal antibody to a specific oligosaccharide sequence on a mouse teratocarcinoma antigen also binds to caudaepididymidal spermatozoa, but not testicular cells. The correct array of surface glycoproteins on spermatozoa may be important during fertilization, since the initial events involve complementary recognition and membrane fusion between sperm and egg.

Thus evidence suggests that maturation changes to the plasma membrane of spermatozoa involves both uptake of regulatory proteins from the caudaepididymidal plasma, and modification of existing membrane antigens by glycosylation.

We are grateful to Mr. K. I. von Glos for technical assistance and to Mrs. M. Mansfield and Mrs. J. Constable for typing the manuscript.

\section{References}

Bedford, J. M. (1975) in Handbook of Physiology (Hamilton, D. W. \& Greep, R. O., eds.), vol. 5, pp. 301-307, Williams and Wilkins Co., Baltimore

D'Agostino, A., Jones, R., White, R. \& Parker, M. G. (1980) Biochem. J. 190, 505-512

Feizi, T. (1981) Trends Biochem. Sci. 6 (12), 333-335

Fitzgerald, D. K., Colvin, B., Mawal, R. \& Ebner, K. E. (1970) Anal. Biochem. 36, 43-61

Fox, N., Damjanov, I., Knowles, B. B. \& Solter, D. (1982) Exp. Cell Res. 137, 485-488

Gaunt, S. J. (1982) Dev. Biol. 89, 92-100

Hamilton, D. W. (1980) Biol. Reprod. 23, 377-388

Hamilton, D. W. (1981) Biol. Reprod. 25, 385-392

Johnson, G. D., Holborow, E. J. \& Dorling, J. (1978) in Handbook of Experimental Immunology (Weir, D. M., ed.), 3rd edn., pp. 15.1-15.30, Blackwell Scientific Publications, Oxford

Jones, R. (1979) Comp. Biochem. Physiol. 61B, 365-370

Jones, R., Brown, C. R., von Glos, K. I. \& Parker, M. G. (1980) Biochem. J. 188, 667-676

Jones, R., von Glos, K. I. \& Brown, C. R. (1981a) Biochem. J. 196, 105-114

Jones, R., Pholpramool, C., Setchell, B. P. \& Brown, C. R. (1981b) Biochem. J. 200, 457-460

Lachmann, P. J. \& Hobart, M. J. (1978) in Handbook of Experimental Immunology (Weir, D. M., ed.), 3rd edn., pp. 5A.1-5A.23, Blackwell Scientific Publications, Oxford

Lea, O. A., Petrusz, P. \& French, F. S. (1978) Int. J. Androl. Suppl. 2, 592-607

Lopo, A. C. \& Vacquier, V. D. (1980) Dev. Biol. 79, 325-333

Moore, H. D. M. (1981) J. Exp. Zool. 215, 77-86

Owen, M. J., Knott, J. C. A. \& Crumpton, M. J. (1980) Biochemistry 19, 3092-3099

Towbin, H., Staehelin, T. \& Gordon, J. (1979) Proc. Natl. Acad. Sci. U.S.A. 76, 4350-4354 